\title{
Article \\ Prioritization of Critical Areas on Hydrological Response Unit Level for Sediment and Nutrient loss control in a River Basin of India
}

\author{
Dhiraj Khalkho ${ }^{1,}{ }^{*}$, M. P. Tripathi ${ }^{2}$, S. Patel ${ }^{3}$, Nadhir Al-Ansari ${ }^{4}$, Love Kumar ${ }^{5}$, Atish Sagar ${ }^{6}$, Prashant Singh ${ }^{6}$, \\ Vijay Kumar Singh ${ }^{7}$, Dinesh Kumar Vishwakarma ${ }^{8,}{ }^{*}$ and Ahmed Elbeltagi ${ }^{9}$
}

1 Senior Scientist, Department of Soil and Water Engineering, Swami Vivekanand College of Agricultural Engineering \& Technology and Research Station, Faculty of Agricultural Engineering, Indira Gandhi Krishi Vishwavidyalaya, Raipur, Chhattisgarh 492012 India; dkhalkho@rediffmail.com

2 Professor and Head, Department of Soil and Water Engineering, Swami Vivekanand College of Agricultural Engineering \& Technology and Research Station, Faculty of Agricultural Engineering, Indira Gandhi Krishi Vishwavidyalaya, Raipur, Chhattisgarh 492012 India; mktripathi64@gmail.com

3 Professor, Department of APFE, Swami Vivekanand College of Agricultural Engineering \& Technology and Research Station, Faculty of Agricultural Engineering, Indira Gandhi Krishi Vishwavidyalaya, Raipur, Chhattisgarh 492012 India; patels47@rediffmail.com

4 Department of Civil, Environmental and Natural Resources Engineering, Lulea University of Technology, 97187 Lulea, Sweden; nadhir.alansari@ltu.se, https://orcid.org/0000-0002-6790-2653

5 Research Associate, Centre for Protection Cultivation Technology, Indian Agricultural Research Institute, New Delhi 110012, India; loverajfae@gmail.com

6 Division of Agricultural Engineering, Indian Agricultural Research Institute, New Delhi 110012, India; atishmicky.sagar@gmail.com (Atish Sagar), prashant95032@gmail.com (Prashant Singh)

7 Faculty of Agriculture Science and Technology, Mahatma Gandhi Kashi Vidhyapith, Varanasi, Uttar Pradesh 221002, India; vijaysinghswce@gmail.com, https://orcid.org/0000-0002-9046-150X

8 Department of Irrigation and Drainage Engineering, College of Technology, G.B. Pant University of Agriculture and Technology, Pantnagar, Uttarakhand 263145, India; https://orcid.org/0000-0002-2421-6995

9 Agricultural Engineering Department, Faculty of Agriculture, Mansoura University, Mansoura 35516, Egypt; ahmedelbeltagy81@mans.edu.eg, https://orcid.org/0000-0002-5506-9502

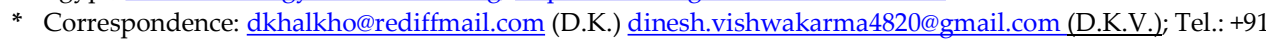
9670791406

\begin{abstract}
Mahanadi is one of the major inter-state east flowing perennial rivers in peninsular India. Hamp watershed of Seonath Sub-basin of upper Mahanadi basin was considered for the study to estimate the sediment yield and nutrient loss-based identification of critical agricultural sub-watershed and its critical Hydrological Response Unit (HRU) using Soil and Water Assessment Tool (SWAT) interfaced with GIS i.e., ArcSWAT. The study area was divided into 14 sub-watersheds considering topographical parameters derived from DEM and drainage network. The land cover, soil layers, and DEM were used to generate 207 HRUs for analysis of annual runoff, sediment yield and nutrient loss for 2004-2008 (calibration period) and 2010-2013 (validation period). The sediment yield, runoff estimation and nutrient loss matched consistently well with the monthly and seasonal measured values. On the basis of average annual sediment yield (18.18 t/ha), runoff (245.97 mm) and nutrient loss $\mathrm{NO}_{3}-\mathrm{N}(1.62 \mathrm{~kg} / \mathrm{ha})$, respectively, sub-watershed WS4 was categorized under high priority for critical are identification. The sub watershed WS4 comprises of 15 HRUs (No. 36 - 50) with four kharif crops viz rice, soybean, maize and sugarcane. Results showed that the crops soybean, maize and sugarcane reduced the average annual runoff by 18.1, 31.4 and 18.0 per cent, respectively whereas the sediment yield was increased drastically by 104.5, 37.5 and 5.7 per cent, respectively as compared to rice. Soybean and maize crops HRU generate significant amount of soil and nutrient loss and were found to be as the critical HRUs for the upper Mahanadi River basin.
\end{abstract}

Keywords: Sediment yield; runoff; SWAT; Watershed; Hydrological model; Hydrological Response Units; Critical area. 


\section{Introduction}

The Land and water are the basic natural resources and must be conserved as effectively as possible. Water is a basic necessity for the survival of living beings and is the most precious natural resource which supports the existence of life on earth. Soil is the most fundamental, basic and natural resource on earth, which is essential for survival of human being [1]. Hydrologic and water quality investigations are fundamental to any watershed management programme. Identification and prioritization of critical erosion prone areas is an important consideration for policy makers to implement best management strategies that are more sustainable in future for long term use of these natural resources [2]. Application of physically based distributed parameter models, remote sensing technique and geographic information system can assist planners in both identifying the most vulnerable erosion prone areas and selecting appropriate management practices [3]. Studies have indicated that, for many watersheds, a few critical areas are responsible for disproportionate amount of the pollution [4-7]. Against this background, it is of utmost importance to understand the behavior of different hydrological processes in any river basin for development of any watershed management plan.

In recent years, hydrologists have been working on developing new models or improving existing ones for efficient simulation of watershed hydrology. As noted by Singh et al. [8] this has resulted in a large number of hydrologic models, and many more are likely to emerge in the near future. Soil and Water Assessment Tool (SWAT) is a river basin or watershed scale model and is successfully used for simulating runoff, sediment yield and water quality to predict the impact of land management practices on water, sediment and agricultural chemical yields in large, complex watersheds with varying soils, land use and management conditions over long periods of time. The SWAT model can be used in data scarce or ungauged catchments for identifying hydrological controlling parameters [9]. The ArcSWAT, the ArcGIS extension, is a graphical user interface for the distributed parameter model SWAT model [10]. SWAT can be used to simulate a single watershed or a system of multiple hydrologically connected watersheds. SWAT uses a two-level disaggregation scheme; a preliminary sub-basin identification is carried out based on topographic criteria, followed by further discretization using land use and soil type considerations. Areas with the same soil type and land use form a Hydrologic Response Unit (HRU), a basic computational unit assumed to be homogeneous in hydrologic response to land cover change. The ArcSWAT has capability to run with more than 1000 numbers of Hydrologic Response Units (HRUs) under various management schemes.

The present study was carried out with ArcSWAT model to prioritize the critical HRU of the prioritized critical sub-watershed of Hamp watershed based on the runoff generated, sediment yield and nutrient loss and thereafter development of best management practice for the control of the same.

\section{Materials and Methods}

\subsection{Study Area}

The The Hamp watershed in Seonath sub-basin of upper Mahanadi basin was selected for the present study with Andhiyarkhore gauging station of Central Water Commission (CWC) as its outlet. Hamp River is the main stream of the Hamp watershed as shown in Figure 1. It originates from Kawardha district and passes through newly formed Bemetara district and joins Seonath River at Raipur district of Chhattisgarh state, India. The study area lies between $81^{\circ} 01^{\prime} \mathrm{E}$ to $81^{\circ} 36^{\prime} \mathrm{E}$ and $21^{\circ} 45^{\prime} \mathrm{N}$ to $22^{\circ} 30^{\prime} \mathrm{N}$ with an altitude ranging from $267-1193 \mathrm{~m}$ above the mean sea level (MSL) covering a total geographical area of $2210 \mathrm{sqkm}$. Hamp River is situated at the uppermost boundary of the Mahanadi basin and the area is dominated by upland farming situations promoting soil loss with poor crop productivity. Farming situation of Chhattisgarh agro-climatic zone is divided into four types viz Bhata (Entisols), Matasi (Inceptisols), Dorsa (Alfisols) and Kanhar (Vertisols). Bhata lands are the uplands governed by slope $>5 \%$, soil depth of less than $30 \mathrm{~cm}$ 
with soil texture of loamy fine sand to silt loam. In recent years, most soil loss from upland areas occurs as gully erosion [11]. The soils having low infiltration capacity pose challenges for management of runoff and erosion [12]. Therefore, the Hamp watershed of upper Mahanadi River basin was selected as study watershed to estimate the soil loss for identifying and prioritizing critical sub-watersheds and its critical HRU for effective control of sediment and nutrient loss.
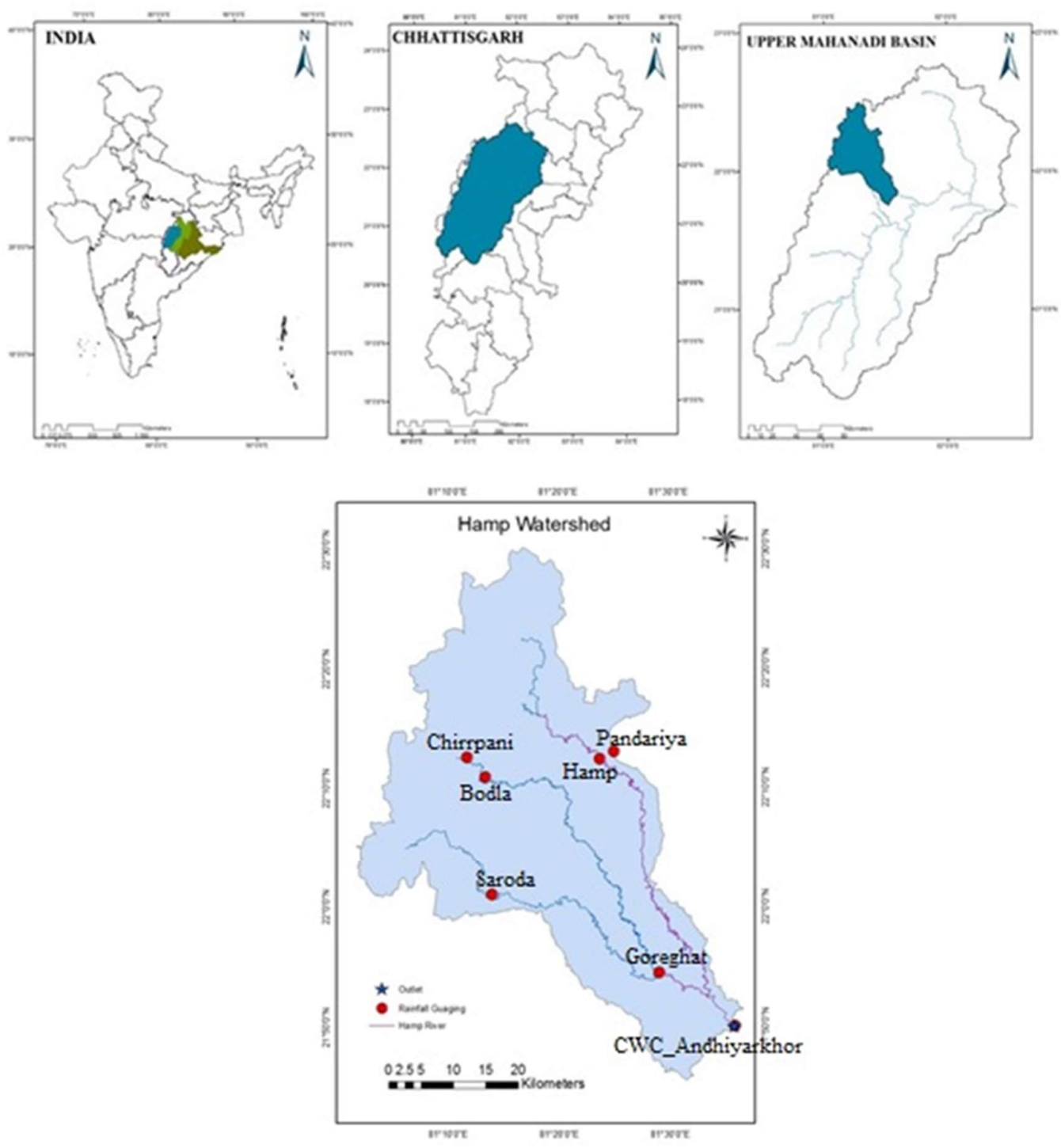

Figure 1. Location map of the study area.

\subsection{Meteorological data}

Long term daily rainfall data for 31 years (1983-2013), measured at the outlet of the Hamp watershed at Andhiyarkhore gauging station of Central Water Commission (CWC), Bhubaneswar, Government of India were collected and analysed to determine the mean monthly rainfall. Maximum and minimum air temperatures recorded at the meteorological observatory of Andhiyarkhore gauging station (1983-2013) was also acquired from the CWC, Bhubaneswar. Daily rainfall data (2004-2013) were also collected from the Hydrology Data Center, Department of Water Resources, Government of Chhattisgarh for six rainfall gauging stations namely Goreghat, Hamp-Pandariya, Balod, Chhirpani, Pandariya and Saroda, which were lying within the Hamp watershed. Nearly more than 10 years rainfall data was available for all the gauging stations and were used in the study. 
Observed data (2004-2013) on rainfall, maximum and minimum temperatures, sunshine hour, relative humidity and wind velocity were also acquired from Bilaspur meteorological observatory, which was close to the Hamp watershed. Due to non-availability of observed data for other meteorological parameters (solar radiation, wind velocity and relative humidity) for the above mentioned six rainfall gauging stations, the same was downloaded from Prediction of Worldwide Energy Resource (POWER) climatology resource for Agro-climatology website. Monthly average values for 10 years (2004-2013) for the rainfall, temperature, relative humidity, wind velocity and solar radiation for Hamp watershed was used in the study. The rainfall data from all the stations was averaged using Thiessen polygon method and other parameters were also averaged.

\subsection{Hydrological and sediment data}

Daily river discharge and sediment yield data (2004-2013) recorded at the outlet of the Hamp watershed, i.e., Andhiyarkhore gauging station was acquired from CWC Regional office, Mahanadi \& Eastern Rivers Organization, Bhubaneswar for the study. A large number of missing data were observed during the monsoon period of year 2009, and hence, it was not considered for both calibration and validation periods.

\subsection{Digital elevation model}

In this study, Shuttle Radar Topographic Mission (SRTM) Digital Elevation Model (DEM) of National Aeronautics and Space Administration (NASA) was used. The Consultative Group on International Agricultural Research- Consortium for Spatial Information (CGIAR-CSI) GeoPortal provides SRTM 90m/30m Digital Elevation Data for most part of the globe (http://srtm.csi.cgiar.org/). The SRTM data was available at 1 arc second (approximately $30 \mathrm{~m}$ spatial resolution) DEMs for the study area (Figure 2).

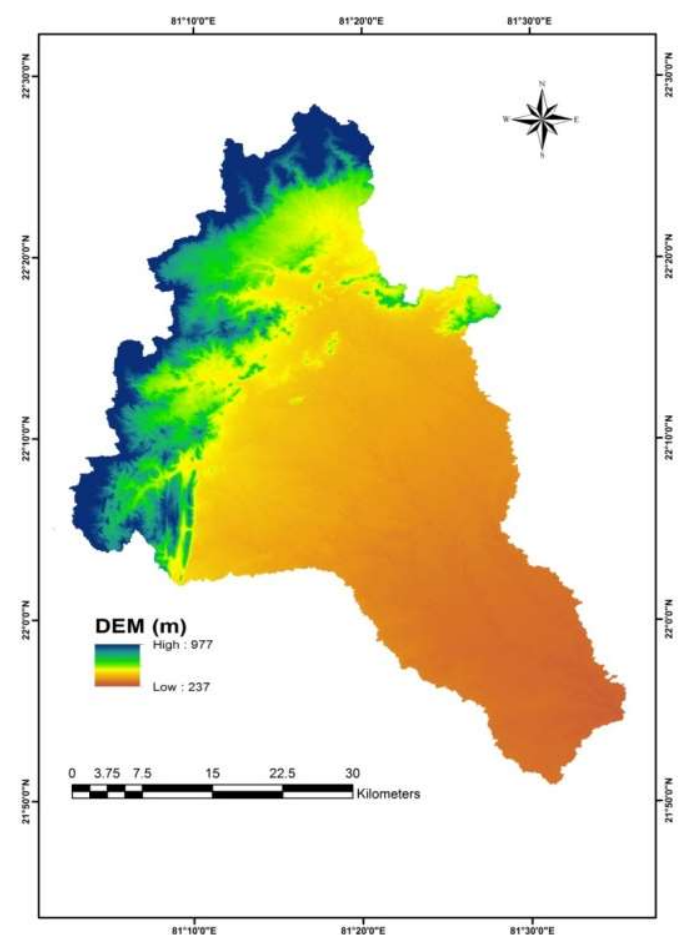

Figure 2. -1 arc SRTM DEM of Hamp Watershed.

Before using the downloaded DEM, it is required to apply the geometric correction. Therefore, the SRTM DEM was re-projected to Universal Transverse Mercator (UTM) coordinate system with Datum WGS 1984 (Zone-44) with spatial resolution of $30 \mathrm{~m}$. 


\subsection{Land Use/Cover}

The cloud free LANDSAT (TM) imagery of 20/10/2008 and 31/10/2013 of the study area was downloaded from Earth Explorer website (https://earthexplorer.usgs.gov) with a spatial resolution of $30 \mathrm{~m}$. The approximate scene size was $170 \mathrm{~km}$ north-south by 183 $\mathrm{km}$ east-west and the whole study area was covered in one scene only. The land use/cover map of the study area was generated using ERDAS IMAGINE 2016. Most common land use classification method, the supervised classification was used in this study. Maximum Likelihood Classifier (MLC) module was used for classifying the land uses. The classification was carried out using Ground Control Points (GCPs). These GCPs were taken with the help of hand-held Global Positioning System (GPS) during field visit of the study area. Each pixel in the image data set was then categorized into the land use class it most closely resembled. The classified land use/cover classes were water body, rainfed paddy, irrigated paddy, soybean, sugarcane, maize, barren land, settlement and forest. The area covered by each class as identified by supervised classification is given in Table 1. Land use land cover data of 2008 was used for the delineation of watershed and sub-watersheds.

Table 1. Pixel based land use/cover classification along with Accuracy assessment of Landsat satellite False Color Composite (FCC) data.

\begin{tabular}{|c|c|c|c|c|c|c|c|c|c|}
\hline \multirow[t]{3}{*}{ Land use classes } & \multicolumn{9}{|c|}{ Pixel Based classification } \\
\hline & \multicolumn{4}{|c|}{2008} & \multicolumn{4}{|c|}{2013} & \multirow{2}{*}{$\begin{array}{l}\text { \% Area } \\
\text { Change }\end{array}$} \\
\hline & Area (ha) & $\%$ Area & $\begin{array}{c}\text { Producers } \\
\text { Accuracy }\end{array}$ & $\begin{array}{c}\text { Users Ac- } \\
\text { curacy }\end{array}$ & Area (ha) & $\%$ Area & $\begin{array}{c}\text { Producers } \\
\text { Accuracy }\end{array}$ & $\begin{array}{c}\text { Users Ac- } \\
\text { curacy }\end{array}$ & \\
\hline Water & 886.5 & 0.4 & $100 \%$ & $100 \%$ & 986.5 & 0.45 & $100 \%$ & $100 \%$ & 0.05 \\
\hline Forest-mixed & 55401.0 & 25.07 & $88 \%$ & $84 \%$ & 51401.0 & 23.26 & $90 \%$ & $80 \%$ & -1.81 \\
\hline Sugarcane & 16257.4 & 7.36 & $76 \%$ & $93 \%$ & 22356.3 & 10.12 & $79 \%$ & $86 \%$ & 2.76 \\
\hline Rice- irrigated & 21179.5 & 9.58 & $79 \%$ & $95 \%$ & 21978.9 & 9.95 & $79 \%$ & $77 \%$ & 0.36 \\
\hline Soybean & 26658.0 & 12.06 & $97 \%$ & $97 \%$ & 33917.7 & 15.35 & $91 \%$ & $97 \%$ & 3.29 \\
\hline Barren & 6953.2 & 3.15 & $50 \%$ & $100 \%$ & 4833.7 & 2.19 & $77 \%$ & $70 \%$ & -0.96 \\
\hline Settlement & 21787.2 & 9.86 & $100 \%$ & $50 \%$ & 22737.5 & 10.29 & $93 \%$ & $98 \%$ & 0.43 \\
\hline Rice - rainfed & 31932.3 & 14.45 & $77 \%$ & $91 \%$ & 24942.8 & 11.29 & $91 \%$ & $87 \%$ & -3.16 \\
\hline Maize & 39949.2 & 18.08 & $86 \%$ & $86 \%$ & 37849.6 & 17.13 & $89 \%$ & $80 \%$ & -0.95 \\
\hline Total & 221004.3 & 100 & & & 221004.3 & 100 & & & 0 \\
\hline \multicolumn{3}{|c|}{ Overall Classification accuracy } & \multicolumn{2}{|c|}{$90.81 \%$} & & \multicolumn{4}{|c|}{$89.71 \%$} \\
\hline \multicolumn{3}{|c|}{ Overall Kappa Statistics } & \multicolumn{2}{|c|}{0.87} & & \multicolumn{3}{|c|}{0.885} & \\
\hline
\end{tabular}

\subsection{Soil}

The soil texture map of the Chhattisgarh state, which was prepared by National Bureau of Soil Survey and Land Use Planning (NBSSLUP), Nagpur using $10 \mathrm{~km}^{2}$ grid sampling, was used in the study. The map was further refined and reclassified based on the soil sample analysis and point data of soil health card acquired for Dept. of Agriculture, Govt. of Chhattisgarh. The soil texture found in the study area were clay, gravelly sandy loam, clay loam, silty clay, gravelly sandy clay loam, sandy clay loam and sandy loam.

\subsection{Delineation of watershed and sub-watersheds using ArcSWAT}

Many hydrological models require a watershed to be subdivided into smaller areas sub-watersheds. Each sub-watershed is assumed as homogeneous, with parameters representative of entire sub-watershed. However, the size of a sub-watershed affects the homogeneity assumption, since larger sub-watershed is more likely to have variable conditions within the sub-watershed. Runoff volume was not affected appreciably by the number and size of the sub-watersheds, whereas annual fine sediment yield produced from upland areas was very sensitive to the level of watershed subdivisions [13]. Sub-watershed classification refers to the assessment and management category assigned to a subwatershed [14]. The ArcSWAT uses standard methodology which is based on the eightpour point algorithm [15] to delineate streams from DEM. With the help of the automatic 
watershed delineator of ArcSWAT model, streams from the raster DEM were extracted and based on this the sub-watersheds were delineated.

The sub-watershed delineation is performed by a process of tracing the flow direction from each grid cell until either an outlet cell or the edge of the DEM grid extent is encountered. The interface is provided with two additional setting tools i.e., DEM properties and threshold area in hectares used for the calculation of geomorphic parameters. The boundary of Hamp watershed and its sub-watersheds were delineated using DEM and drainage network of the study area. The delineated watershed and 14 sub-watersheds are shown in Figure 3 and were named as WS1 to WS14. Watershed and sub-watershed boundaries were also delineated automatically with the help of ArcSWAT using DEM. In this study, automatically-delineated watershedhaving $2210 \mathrm{~km}^{2}$ areas was decomposed into 14 subwatersheds and based on the similar land cover, soil layers and DEM, the watershed was classified into 207 HRUs. Afterwards, area of each sub-watersheds and length of stream reaches were calculated and stored as attributes of derived vector themes.

a)

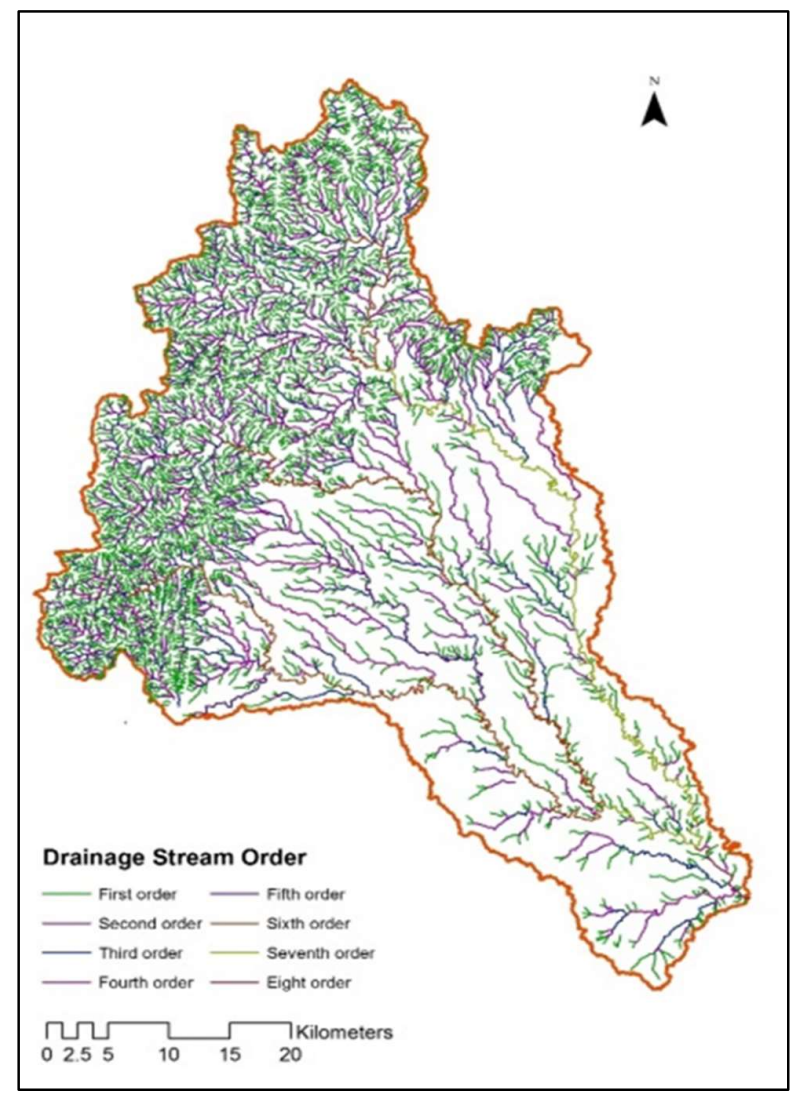


b)

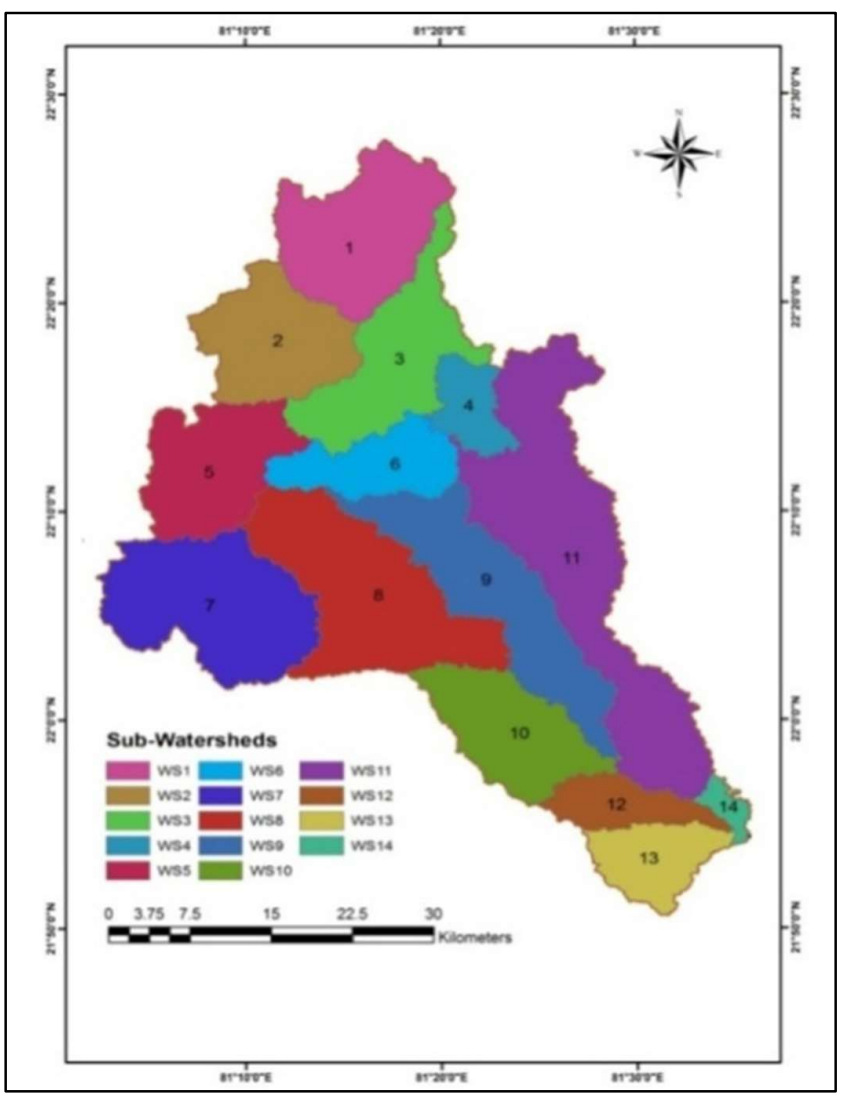

Figure 3. Hamp drainage network and sub-watersheds delineation map.

\subsection{SWAT model}

Research ArcSWAT is a semi-distributed parameter model that operates on a daily or sub-daily time step basis. The first step in the calibration and validation process in ArcSWAT is the determination of the most sensitive parameters for a given watershed or sub-watershed (Arnold et al., 2012). The hydrology model is based on the water balance equation:

$$
\mathrm{SW}_{\mathrm{t}}=\mathrm{SW}+\sum_{\mathrm{i}=1}^{\mathrm{t}}\left(\mathrm{R}_{\mathrm{i}}-\mathrm{Q}_{\mathrm{i}}-\mathrm{ET}_{\mathrm{i}}-\mathrm{P}_{\mathrm{i}}-\mathrm{QR}_{\mathrm{i}}\right)
$$

Where, $\mathrm{SW}$ is the soil water content minus the 15-bar water content, $\mathrm{t}$ is time in days, and $\mathrm{R}, \mathrm{Q}, \mathrm{ET}, \mathrm{P}$, and $\mathrm{QR}$ are the daily amounts of precipitation, runoff, evapotranspiration, percolation, and return flow respectively; all units are in $\mathrm{mm}$. Since the model maintains a continuous water balance, complex basins are subdivided to reflect differences in ET for various crops and soils. Thus, runoff is predicted separately for each sub-area and routed to obtain the total runoff for the basin. This increases accuracy and gives a much better physical description of the water balance. SWAT predicts surface runoff for daily rainfall by using the Soil Conservation Service (SCS) Curve Number (CN) method. Sediment yield was computed for each sub-basin with the Modified Universal Soil Loss Equation (MUSLE).

Sensitivity analysis was performed using the SUFI-2 algorithm of SWAT-CUP. The parameter producing the highest average percentage change in the objective function value is ranked as most sensitive. SWAT-CUP uses the SWAT input files and runs the SWAT simulations by modifying the given parameters. Sensitivity analysis was conducted using a combined method of Latin Hypercube (LH) sampling and One-Factor-Ata-Time (OAT). Each variable was varied within the prescribed range keeping other 
constant. The output of model simulated runoff and sediment yield were analyzed to determine their variation with respect to their respective counterpart observer's values. From sensitivity analysis it was possible to decide which variables need to be precisely estimated to make accurate predictions of the runoff and sediment yields.

The model was calibrated during the monsoon season (June to October) for the years 2004-2008, including three years of warm-up period (2001-2003) using daily average monthly values of the observed runoff and sediment yield along with average seasonal nutrient loss comprising of nitrate nitrogen $\left(\mathrm{NO}_{3}-\mathrm{N}\right)$ and total phosphorous. The model was validated during the monsoon season (June to October) for the years 2010-2013. Annual runoff, sediment and nutrient losses were simulated for each sub-watershed of Hamp watershed using adequately tested calibrated and validated ArcSWAT model for identification and prioritization of critical sub-watersheds. Thereafter from the prioritized critical sub watershed, the critical HRU was prioritized based on the runoff, sediment yield and nutrient loss. Priorities were fixed on the basis of ranks assigned to each critical sub-watersheds based on the susceptibility to erosion [8]. Also, for nutrient losses a threshold value of $10 \mathrm{mg} / \mathrm{l}$ for nitrate nitrogen and $0.5 \mathrm{mg} / \mathrm{l}$ for dissolve phosphorous as described by USEPA [16] were considered as criterion for identifying the critical sub-watersheds.

\subsection{Criteria for Model Evaluation}

Several types of statistics provide useful numerical measures of the degree of agreement between models simulated and recorded quantities. The numerical criteria as described in Table 2 was used in the study.

Table 2. Details of Criteria for Model Evaluation.

\begin{tabular}{|c|c|c|c|c|}
\hline S. No. & Criteria for Model Evaluation & & Equation & References \\
\hline \multirow[t]{2}{*}{1} & Coefficient of determination $\left(\mathrm{R}^{2}\right)$ & \multirow{2}{*}{$\mathrm{R}^{2}=$} & $\sum_{\mathrm{i}=1}^{\mathrm{N}}\left(\mathrm{Y}_{\mathrm{i}}^{\text {obs }}-\mathrm{Y}_{\text {mean }}^{\text {obs }}\right)\left(\mathrm{Y}_{\mathrm{i}}^{\text {sim }}-\mathrm{Y}_{\text {mean }}^{\text {sim }}\right)$ & \multirow[t]{2}{*}[17,18]{} \\
\hline & & & {$\left[\sum_{i=1}^{\mathrm{N}}\left(Y_{i}^{\text {obs }}-Y_{\text {mean }}^{\text {obs }}\right)\right]^{0.5}\left[\sum_{i=1}^{\mathrm{N}}\left(Y_{i}^{\text {sim }}-Y_{\text {mean }}^{\text {sim }}\right) 2\right]^{0.5}$} & \\
\hline \multirow[t]{2}{*}{2} & Nash-Sutcliffe efficiency (ENS) & & $\left.F_{i=1}^{n}\left(Y_{i}^{\text {obs }}-Y_{i}^{\text {sim }}\right)^{2}\right]$ & \multirow[t]{2}{*}[19,20]{} \\
\hline & & & $\mathrm{E}_{\mathrm{NS}}=1-\left[\overline{\sum_{\mathrm{i}=1}^{\mathrm{n}}\left(\mathrm{Y}_{\mathrm{i}}^{\text {obs }}-\mathrm{Y}_{\text {mean }}^{\text {obs }}\right)^{2}}\right]$ & \\
\hline \multirow[t]{2}{*}{3} & \multirow[t]{2}{*}{ Percent bias (PBIAS) } & & PRIAS $-\left[\sum_{\mathrm{i}=1}^{\mathrm{n}}\left(\mathrm{Y}_{\mathrm{i}}^{\mathrm{obs}}-\mathrm{Y}_{\mathrm{i}}^{\text {sim }}\right) \times 100\right]$ & \multirow[t]{2}{*}[21]{} \\
\hline & & & PBIAS $=\left[\begin{array}{l}\sum_{\mathrm{i}=1}^{\mathrm{n}}\left(\mathrm{Y}_{\mathrm{i}}^{\mathrm{obs}}\right) \\
\end{array}\right.$ & \\
\hline
\end{tabular}

In this study, criterion suggested by Moriasi et al. [22] has been adopted to analyze the performance of the SWAT model as shown in Table 3.

Table 3. General performance ratings for recommended statistics

\begin{tabular}{llll}
\hline Performance rating & ENS & PBIAS (\%) & PBIAS (\%) \\
\hline Unsatisfactory & $\mathrm{E}_{\mathrm{NS}}<0.50$ & PBIAS $> \pm 25$ & PBIAS $>+55$ \\
Satisfactory & $0.50<\mathrm{E}_{\mathrm{NS}}<0.65$ & $\pm 15<\mathrm{PBIAS}< \pm 25$ & $\pm 30<$ PBIAS $< \pm 55$ \\
Good & $0.65<\mathrm{E}_{\mathrm{NS}}<0.75$ & $\pm 10<$ PBIAS $< \pm 15$ & $\pm 15<$ PBIAS $< \pm 30$ \\
\hline
\end{tabular}

\section{Results and Discussion}

Regression analysis was performed between the observed and pre-calibrated monthly runoff values. Statistical indicators such as the coefficient of determination, Nash-Sutcliffe coefficient and Percent bias were used to test the results of model simulation. The overall deviation between the observed and pre-calibrated simulated discharge was found to be $43.94 \%$ which is quite high and makes essential for the model to be calibrated.

\subsection{Parameter used for model calibration}

The calibration procedure involves rigorous manual adjustment, through the manual calibration tool for the ArcSWAT model parameters until acceptable simulation was 
achieved. The default model value and calibrated values used in the ArcSWAT model are presented in Table 4.

Table 4. Initial and calibrated parameter values.

\begin{tabular}{cccc}
\hline S. N. & Parameter & Default values & Calibrated values \\
\hline 1 & CN & $72-91$ & $68.4-86.5$ for agricultural cover \\
& & $60-73$ & $55.5-67.5$ for forest \\
& & $59-72$ & $54.6-66.6$ for settlements \\
2 & RCHRG_DP & 0.05 & 0.46 \\
3 & ESCO & 0.95 & 0.50 \\
4 & SOL_AWC & $0-0.23$ & $0-0.253$ \\
5 & GWQMN & 0 & 60 \\
6 & EPCO & 1 & 0.75 \\
7 & GWREVAP & 0.02 & 0.15 \\
8 & CH_K2 & 0 & 25 \\
9 & CH_N2 & 0.014 & 0.025 \\
10 & Alphabf & 0.0482 & 0.193 \\
11 & GW Delay & 31 & 15 \\
12 & USLE_P & $0.01-1$ & 0.65 \\
13 & CH_COV & $0-1$ & 0.71 \\
14 & CH_EROD & $0-1$ & 0.61 \\
\hline
\end{tabular}

3.2. Calibration of the model for monthly runoff simulation

The time series of the observed and simulated monthly runoff values of Hamp watershed for the calibration period were compared as 1:1 scatter plot and are presented in Figure 4. It is observed that the simulated runoff follows the plot of the observed runoff. Further, efficiency of model for simulating runoff was tested by statistical analysis and the results are observed during calibration $\left(E_{N S}=0.942\right.$, PBIAS $=1.147, \mathrm{R}^{2}=0.943$ ) for the period of 2004 to 2008 (Table 5). The magnitude of the simulated monthly runoff was found higher than that of observed runoff for most of the months as is reflected by the positive value of PBIAS. Generally, it was found that during the initial phase of initiation of monsoon rains, the observed runoff was less than the simulated runoff. This may be due to the fact that significant portion of the rainfall is stored in the bunded paddy fields. $\mathrm{R}^{2}$ and ENs show good relationship between the observed and simulated monthly runoff data during the whole calibration period explaining acceptable and minimum deviation between the monthly observed and simulated values.

\subsection{Validation of the model for monthly runoff simulation}

The 1:1 scatter line plot comparison of simulated and measured monthly runoff for the monsoon period is shown in Figure 4. The results of the monthly runoff validation along with comparison of simulated and measured monthly runoff are shown in Table 5. The model validation with a high $\mathrm{R}^{2}$ value $(0.923)$ indicated a close relationship between measured and simulated runoff which is also satisfied by ENs value of 0.914 and PBIAS value of 5.80 .

\subsection{Calibration of the model for monthly sediment yield}

It is evident from the Figure 5 that the simulated sediment yield closely follows the trend of observed sediment yield. Performance criteria (Table 6) showed a close relationship between observed and simulated sediment yields during calibration (ENS $=0.94$, PBIAS $=-19.724, \mathrm{R}^{2}=0.963$ ). The overall prediction of the monthly sediment yield during the whole calibration period was in very good agreement with its observed values. 
Table 5. Model performance during calibration (2004-2008) and validation period (2010-2013) in simulating monthly runoff.

\begin{tabular}{cccccccccc}
\hline \multirow{2}{*}{ Year } & \multicolumn{4}{c}{ Observed } & \multicolumn{3}{c}{ Simulated } & \multicolumn{2}{c}{ Validation } \\
\cline { 2 - 10 } & Mean & Max & Std Dev & Mean & Max & Std Dev & Ens & PBIAS $^{2}$ \\
\hline $2004-2008$ & 24.770 & 99.248 & 28.64 & 24.46 & 109.62 & 26.77 & 0.942 (Very Good) & 1.147 (Very Good) & 0.943 \\
$2010-2013$ & 25.75 & 84.51 & 24.65 & 24.26 & 78.94 & 21.87 & 0.914 (Very Good) & 5.80 (Very Good) & 0.923 \\
\hline
\end{tabular}

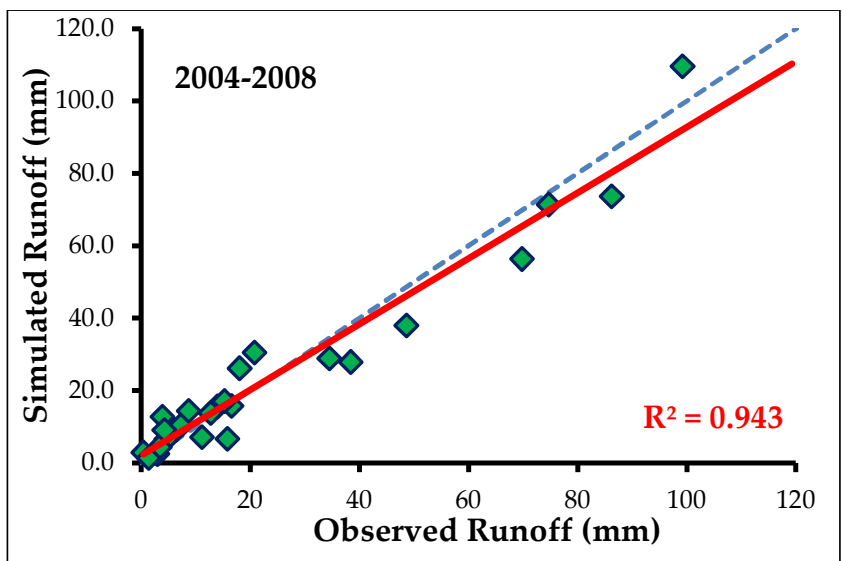

(a)

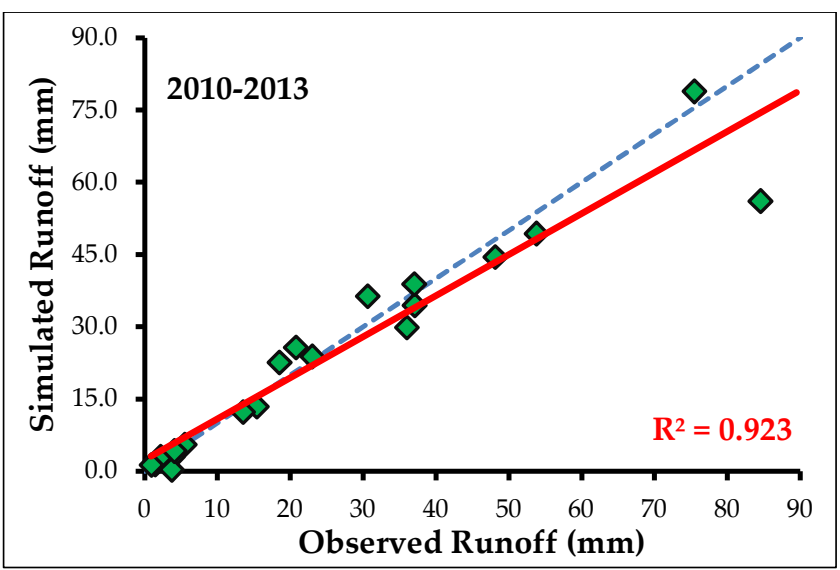

(b)

Figure 4. Scatter plot of simulated and observed monthly runoff ( $\mathrm{mm})$ during a) calibration; and b) validation period.

\subsection{Calibration of the model for monthly sediment yield}

The time of peak sediment yield in case of predicted graph matched consistently well with the measured sediment graph throughout the season. However, the model-predicted values were sometimes higher and sometimes lower than the observed values during the validation period (Figure 5). A high $\mathrm{R}^{2}$ value of 0.950 indicates a close relationship between measured and simulated monthly sediment yields (Table 6). The Ens value of 0.941 indicated a very good agreement between observed and simulated sediment. The marginal deviation of PBIAS (-9.633 \%) of simulated sediment yield from observed sediment yield indicated that the model was predicting sediment yield quite well. However, the model slightly over-predicted few events of sediment yield.

Table 6. Model performance during calibration (2004-2008) and validation period (2010-2013) in monthly sediment yield.

\begin{tabular}{cccccccccc}
\hline Year & \multicolumn{4}{c}{ Observed } & \multicolumn{3}{c}{ Simulated } & \multicolumn{2}{c}{ Validation } \\
\cline { 2 - 9 } & Mean & Max & Std Dev & Mean & Max & Std Dev & ENs & PBIAS $^{\mathbf{R}^{2}}$ \\
\hline $2004-2008$ & 0.825 & 3.631 & 1.004 & 0.988 & 3.890 & 0.989 & 0.940 (Very Good) & $-19.724($ Good) & 0.963 \\
$2010-2013$ & 1.113 & 4.737 & 1.282 & 1.220 & 4.190 & 1.190 & 0.941 (Very Good) & -9.633 (Very Good) 0.950 \\
\hline
\end{tabular}




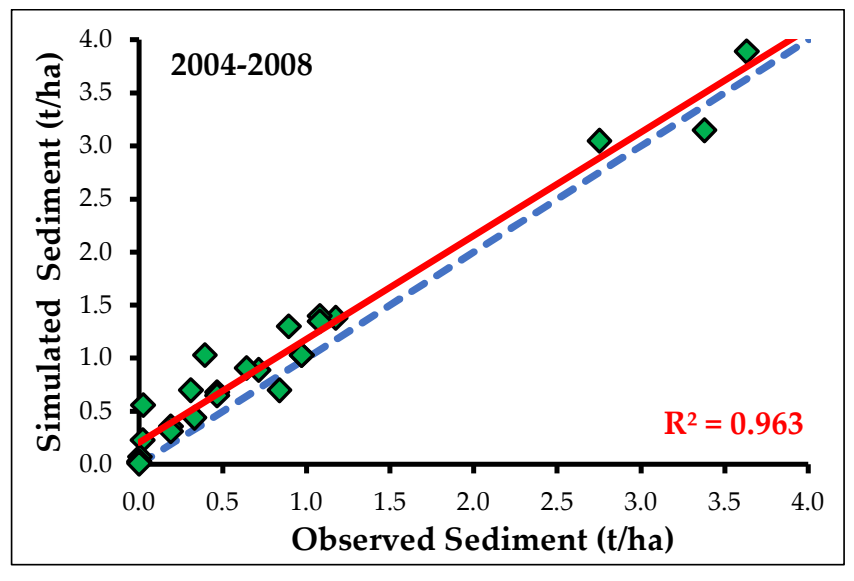

(a)

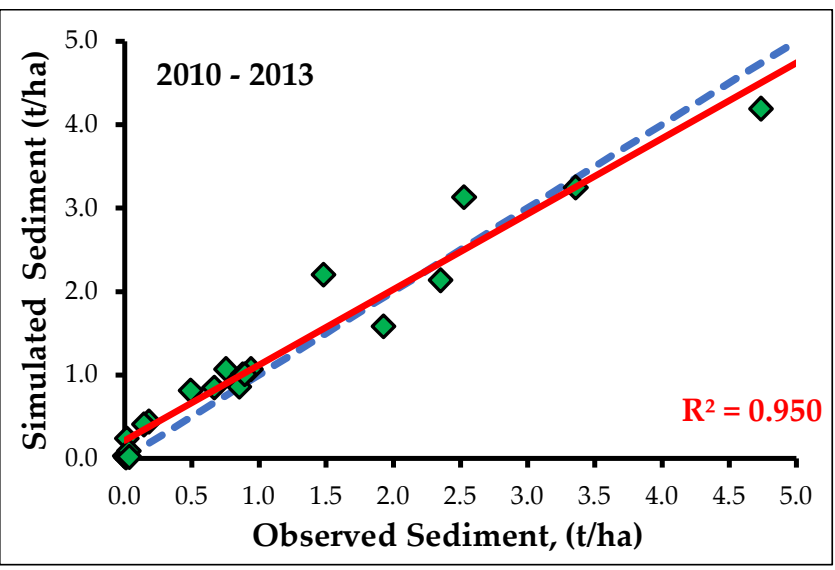

(b)

Figure 5. Scatter plot of simulated and observed monthly sediment yield ( $\left.\mathrm{t} \mathrm{ha}^{-1}\right)$ during a) calibration; and b) validation period.

\subsection{Calibration of the model for seasonal nutrient loss}

As per the availability of data, the time series of the observed and simulated seasonal nitrate nitrogen $\left(\mathrm{NO}_{3}-\mathrm{N}\right)$ and total phosphorous (tot-P) values of Hamp watershed for the reduced calibration period were compared by scatter plots along with 1:1 line and presented in Figure 6. Table 7 shows close relationship between observed and simulated nutrient loss as indicated by the values during reduced calibration period (2005-2008) for $\mathrm{NO}_{3}-\mathrm{N}\left(\mathrm{ENS}_{\mathrm{NS}}=0.736, \mathrm{PBIAS}=5.102, \mathrm{R}^{2}=0.746\right)$ shows that the seasonal nitrate nitrogen loss was in acceptable agreement with its observed values.

Table 7. Model performance during calibration period for seasonal Nutrient Loss.

\begin{tabular}{cccccccccc}
\hline Nutrient/ & \multicolumn{3}{c}{ Observed } & \multicolumn{3}{c}{ Simulated } & Validation \\
\cline { 2 - 9 } Year & Mean & Max & Std Dev & Mean & Max & Std Dev & ENs & PBIAS & $\mathbf{R}^{2}$ \\
\hline $\begin{array}{c}\text { NO3-N } \\
(2005-08)\end{array}$ & 0.327 & 1.260 & 0.353 & 0.310 & 0.913 & 0.339 & 0.736 (Good) & 5.102 (Very Good) & 0.746 \\
$\begin{array}{c}\text { Tot- P } \\
(2004-08)\end{array}$ & 0.081 & 0.651 & 0.055 & 0.092 & 0.734 & 0.064 & 0.900 (Very Good) & -12.75 (Good) & 0.908 \\
\hline
\end{tabular}

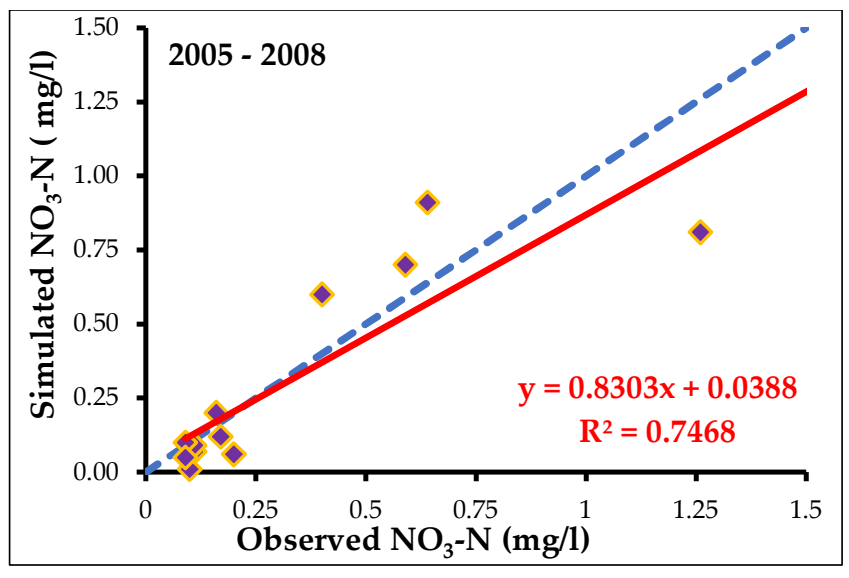

(a)

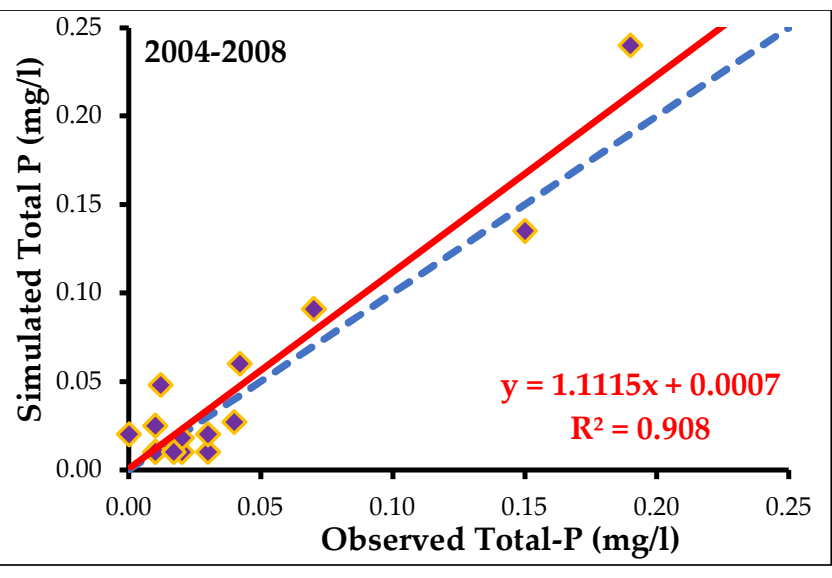

(b)

Figure 6. Scatter plot of simulated and observed seasonal nutrient loss a) $\mathrm{NO}_{3}-\mathrm{N}$ and b) Total-P, mg/l) during calibration period. 
In case of total-P loss, coefficient of determination (0.908) and ENs (0.90) indicated good agreement between observed and simulated data. The observed and simulated values of total-P were evenly distributed about the 1:1 scatter line (Figure 6). The PBIAS value reflects that the model is over predicting phosphorous by $12.75 \%$ (Good). Model was considered good for predicting seasonal nitrate nitrogen and total phosphorous loss from Hamp watershed.

\subsection{Validation of the model for seasonal nutrient loss}

During the whole validation period 2010-2013, the data of nitrate nitrogen $\left(\mathrm{NO}_{3}-\mathrm{N}\right)$ was not available and so this nutrient parameter was not considered for validation. The validation was carried out for total Phosphorous (tot-P) only during the period 2010-2013. The time series of the observed and simulated seasonal total-P loss values of Hamp watershed for the validation period were compared by scatter plots along with 1:1 line and are presented in Figure 7. The comparison between observed and simulated values of total phosphorous indicated that the simulated values were close to the observed values of total phosphorous. A coefficient of determination $\left(\mathrm{R}^{2}\right)$ of 0.751 also indicated good agreement between observed and simulated total phosphorous. Descriptive statistics related to observed and simulated total phosphorous is given in Table 8. The PBIAS value was found to be $4.81 \%$ indicating that the model was predicting total phosphorous very good with very marginal overall deviations. As the calibration data of $\mathrm{NO}_{3}-\mathrm{N}$ also presented a good correlation between the observed and simulated values, so it is evident that the model is predicting nutrient loss from Hamp watershed of upper Mahanadi River Basin very well.

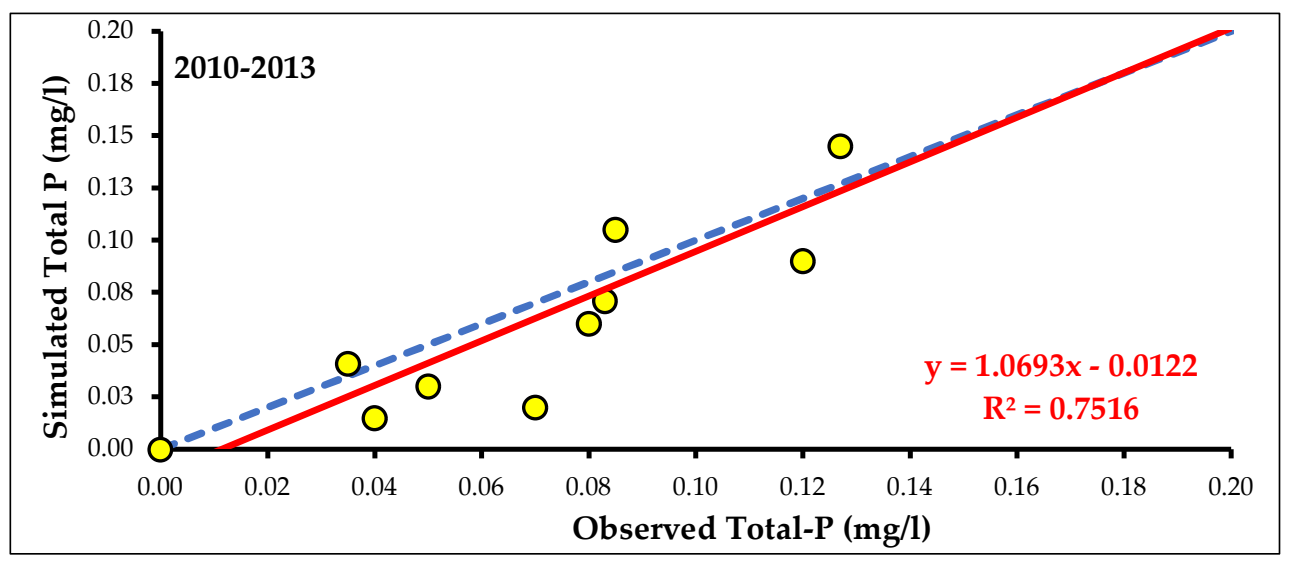

Figure 7. Scatter plot of simulated and observed seasonal nutrient loss (Total-P, mg/l) during validation period.1 arc SRTM DEM of Hamp Watershed.

Table 8. Model performance during validation period for Nutrient Loss (Tot- P, mg/l).

\begin{tabular}{cccccccccc}
\hline Nutrient/ & \multicolumn{4}{c}{ Observed } & \multicolumn{3}{c}{ Simulated } \\
\cline { 2 - 9 } Year & Mean & Max & Std Dev & Mean & Max & Std Dev & Ens & PBIAS $^{2}$ \\
\hline Tot- P & 0.1 & 0.31 & 0.0898 & 0.10 & 1.187 & 0.248 & 0.615 (Satisfactory) & 4.81 (Very Good) & 0.751 \\
$(2004-08)$ & & & & & & & & \\
\hline
\end{tabular}

\subsection{Identification and Prioritization of Critical Sub-watersheds}

Identification and prioritization of critical sub-watersheds based on actual sediment yield rates may be possible only when sediment data is available. The model was run for the four consecutive years (2010 - 2013) and annual watershed yield including runoff and sediment yield were considered for each sub-watershed and given in Table 9. The ranges of erosion rates and their classes suggested by Singh et al. [8] were used to identify and prioritize the critical sub-watersheds. Out of the fourteen sub-watersheds, the WS3, WS6, WS9, WS12, WS13, WS14 fell under moderate soil loss group of soil erosion classes (5 to $\left.10 \mathrm{t} \mathrm{ha}^{-1} \mathrm{yr}^{-1}\right)$. The WS4, WS8, WS10 and WS11 fell under high soil loss group of soil erosion classes (10 to $20 \mathrm{t} \mathrm{ha}^{-1} \mathrm{yr}^{-1}$ ), whereas other sub-watersheds fell under slight erosion classes. 
Table 9. Model output for identification of the critical sub-watersheds (2010-2013).

\begin{tabular}{ccccccccc}
\hline SWS & $\begin{array}{c}\text { Area, } \\
\text { sqkm }\end{array}$ & $\begin{array}{c}\text { Rainfall, } \\
\mathbf{~ m m}\end{array}$ & Runoff, $\mathbf{m m}$ & $\begin{array}{c}\text { Sediment } \\
\text { Yield, } \mathbf{t} \mathbf{h a}\end{array}$ & $\begin{array}{c}\text { NO3-N, } \\
\text { Kg/ha }\end{array}$ & $\begin{array}{c}\text { Soluble } \mathbf{P}, \\
\mathbf{K g} / \mathbf{h a}\end{array}$ & $\begin{array}{c}\text { Soil erosion } \\
\text { class }\end{array}$ & Priority \\
\hline 1 & 184.88 & 1110.14 & 76.79 & 1.67 & 0.48 & 0.02 & Slight & 11 \\
2 & 149.48 & 1110.69 & 60.68 & 0.99 & 0.16 & 0.02 & Slight & 13 \\
3 & 176.53 & 1110.13 & 157.46 & 6.82 & 0.85 & 0.08 & Moderate & 8 \\
4 & 54.05 & 1001.93 & 245.97 & 18.18 & 1.62 & 0.19 & High & 1 \\
5 & 150.78 & 586.88 & 5.79 & 1.10 & 0.01 & 0.00 & Slight & 12 \\
6 & 96.77 & 530.44 & 32.19 & 8.44 & 0.27 & 0.03 & Moderate & 6 \\
7 & 227.13 & 575.22 & 1.05 & 0.84 & 0.00 & 0.00 & Slight & 14 \\
8 & 254.73 & 980.26 & 137.13 & 15.55 & 0.73 & 0.09 & High & 2 \\
9 & 207.63 & 980.41 & 134.37 & 9.42 & 0.84 & 0.10 & Moderate & 5 \\
10 & 139.72 & 654.53 & 57.76 & 10.17 & 0.47 & 0.05 & High & 4 \\
11 & 411.92 & 1000.12 & 263.10 & 14.73 & 2.02 & 0.19 & High & 3 \\
12 & 62.56 & 654.75 & 71.64 & 6.61 & 0.50 & 0.05 & Moderate & 9 \\
13 & 77.60 & 923.12 & 230.72 & 7.07 & 1.19 & 0.13 & Moderate & 7 \\
14 & 16.26 & 926.12 & 203.67 & 5.41 & 1.36 & 0.14 & Moderate & 10 \\
\hline
\end{tabular}

The results indicated that the dissolved nutrient $\left(\mathrm{NO}_{3}-\mathrm{N}\right.$ and soluble $\left.\mathrm{P}\right)$ losses were within the permissible limit $[8,16]$. The trend showed that losses of nutrient attached with the sediment were proportional to losses of sediment from the watershed (Table 9). The nitrate nitrogen and soluble phosphorous in runoff were high in WS4, WS11, WS13 and WS14 compared to other sub watersheds.

None of the sub-watersheds fell under very high, severe or very severe erosion classes. Though nearly $30 \%$ area is having extremely undulating topography with steep slopes still due to the nearly level topography of the remaining area, average slope is gentle slope. The study watershed might have got stabilized as contour and graded bunds and settlements already exist in the watershed. Sub-watershed WS4 resulted in maximum sediment yield (18.18 t/ha) which is also more than average soil loss of $16.35 \mathrm{t} \mathrm{ha}^{-1} \mathrm{yr}^{-1}$ (Narayana, 1993) along with maximum $\mathrm{NO}_{3}-\mathrm{N}$ losses $(1.62 \mathrm{Kg} / \mathrm{ha})$ and soluble Phosphorous $(0.16$ $\mathrm{kg} / \mathrm{ha}$ ). This may be due to high average surface slope of 9.1 per cent with undulating topography. Sub-watersheds WS8 and WS11 exceeded the prescribed permissible upper limit of $11.2 \mathrm{t} \mathrm{ha}^{-1} \mathrm{yr}^{-1}$ [23] whereas WS10 is very near to the permissible limit.

There are certain limitations of present study that the model does not simulate detailed event-based flood and sediment routing. Precipitation causes considerable errors in runoff estimation, if less numbers of rain gauging stations are used to represent an entire watershed. Even the missing data or non-availability of long-term continuous data was the major limitation of the study.

\subsection{Prioritization of Critical HRU}

Hydrologic response units are portions of a sub-basin that possess unique land use/ crop cover/ soil attributes. HRU is not synonymous to a field, rather it is the total area in the sub-watershed with a particular land use, crop management and soil. ArcSWAT runs under the assumption that there is no interaction between HRUs in one sub-watershed. Runoff, sediment, nutrient etc. are calculated separately for each HRU and then summed up at sub-watershed level. In total 207 HRUs were delineated from 14 sub-watersheds for Hamp watershed. The area wise distribution of land use, soils and slope in the Hamp watershed is shown in Table 10. 
Table 10. Area wise distribution for HRU delineation in Hamp watershed.

\begin{tabular}{cccc}
\hline Particular & & Area, ha & \% Area \\
\hline LANDUSE: & Forest-Mixed (FRST) & 63738.49 & 29.51 \\
Sugarcane (SUGC) & 14995.68 & 6.94 \\
& Residential-Low Density (URLD) & 21484.97 & 9.95 \\
Soybean (SOYB) & 33783.09 & 15.64 \\
Rainfed Rice (RICE) & 22317.59 & 10.33 \\
SOILS: & Maize (MAZE) & 37663.70 & 17.44 \\
& Irrigated Rice (IRIR) & 22011.75 & 10.19 \\
& Gravelly Sandy Clay Loam (GSCL) & 59635.44 & 27.61 \\
Gravelly Sandy Loam (GSLM) & 12446.84 & 5.76 \\
Sandy Clay Loam (SCLM) & 64824.81 & 30.01 \\
Clay Loam (CYLM) & 28472.74 & 13.18 \\
Sandy Loam (SYLM) & 11968.13 & 5.54 \\
Silty Clay (SYCY) & 25198.83 & 11.67 \\
Clay (CLAY) & 13448.46 & 6.23 \\
& $>10 \%$ & 78744.3078 & 36.46 \\
& $5-10 \%$ & 60881.5849 & 28.19 \\
& $2-5 \%$ & 72174.1942 & 33.41 \\
& $0-2 \%$ & 4195.208 & 1.94 \\
\hline \multirow{2}{*}{ SLOPE: } & & &
\end{tabular}

${ }^{*}$ ArcSWAT code is mentioned in parentheses

Critical sub-watershed (WS4) comprises of 15 HRUs (36-50) as mentioned in Table 11.

Table 11. Effect of HRU of sub-watershed (WS4) on average annual yield during monsoon season of 2010-2013.

\begin{tabular}{|c|c|c|c|c|c|c|}
\hline S. N. & HRU & Crop / soil / slope code & Area $\left(\mathbf{k m}^{2}\right)$ & Runoff (mm) & Soil loss (t/ha) & $\mathrm{NO}_{3}-\mathrm{N}(\mathrm{kg} / \mathrm{ha})$ \\
\hline 1 & 36 & SUGC / CYLM / > $10 \%$ & 7.64 & 265.89 & 14.15 & 4.74 \\
\hline 2 & 37 & SOYB / CYLM /5 - 10 & 2.97 & 323.08 & 29.95 & 1.1 \\
\hline 3 & 38 & SOYB / CYLM /10 - 999 & 4.52 & 315.97 & 32.85 & 3.51 \\
\hline 4 & 39 & SOYB / SCLM /5 - 10 & 1.98 & 210.72 & 27.75 & 2.26 \\
\hline 5 & 40 & SOYB / SCLM / 2 - 5 & 1.50 & 212.25 & 18.96 & 1.1 \\
\hline 6 & 41 & Residential / CYLM / 5 - 10 & 4.43 & 230.08 & 11.09 & 0.63 \\
\hline 7 & 42 & Residential / CYLM / > $10 \%$ & 6.38 & 225.08 & 10.67 & 0.86 \\
\hline 8 & 43 & RICE-CHKP / CYLM / 5 - 10 & 1.78 & 241.79 & 13.8 & 0.91 \\
\hline 9 & 44 & RICE-CHKP / CYLM / > 10 \% & 3.08 & 231.85 & 16.65 & 4.55 \\
\hline 10 & 45 & RICE-CHKP / SCLM / 2 - 5 & 2.01 & 146.1 & 7.5 & 1.03 \\
\hline 11 & 46 & RICE-CHKP / SCLM / 5 - 10 & 2.22 & 143.46 & 15.6 & 2.4 \\
\hline 12 & 47 & MAZE-CHKP / CYLM / 5 - 10 & 2.40 & 266.63 & 18.75 & 1.03 \\
\hline 13 & 48 & MAZE-CHKP /CYLM / > $10 \%$ & 3.03 & 255.13 & 25.65 & 4.91 \\
\hline 14 & 49 & MAZE-CHKP / SCLM /2 - 5 & 4.90 & 185.48 & 14.03 & 1.21 \\
\hline 15 & 50 & MAZE-CHKP /SCLM /5 - 10 & 5.22 & 182.72 & 15.24 & 2.55 \\
\hline
\end{tabular}

The identification and prioritization of critical HRUs was depended on the runoff, sediment and nutrient loss from HRU of sub watershed WS4. The simulation results given in Table 11 indicated that the HRU comprises of four kharif crops viz rice, soybean, maize and sugarcane with two types of soil (sandy clay loam and clay loam) with slope range of $2-5 \%, 5-10 \%$ and $>10 \%$. The crops soybean, maize and sugarcane reduced the average annual runoff by $18.1,31.4$ and 18.0 per cent, respectively whereas the sediment yield was 
increased drastically by $104.5,37.5$ and 5.7 per cent, respectively as compared to rice as presented in Table 12. Looking to the above results it can be stated that none of the crop could replace the rice because these all-other crops were yielding high rate of sediment as compared to rice. Soybean (HRU 37, 38, 39 \& 40) was found to be the highest soil loss promoting crop with an average annual value of $27.38 \mathrm{t} / \mathrm{ha}$ making it the most critical crop of the critical watershed followed by maize with an average annual value of $18.42 \mathrm{t} / \mathrm{ha}$. It is also evident from Table 12 that soybean cultivated on slope range of $>10 \%$ generates maximum soil loss followed by slope range $5-10 \%$ and then $2-5 \%$. The nutrient $\mathrm{NO}_{3}-\mathrm{N}$ was also found to be higher in a case of all crops as compared to the rice except maize.

Table 12. Effect of crops on average annual sub-watershed (WS4) yield under existing tillage practices and fertilizer level during monsoon season of $2010-2013$.

\begin{tabular}{cccccc}
\hline Crop & Area $\left(\mathbf{k m}^{2}\right)$ & Runoff $\mathbf{( m m})$ & Sediment $\mathbf{( t / h a )}$ & $\mathbf{N O}_{3}-\mathbf{N} \mathbf{~ ( k g / h a )}$ & Yield (t/ha) \\
\hline Rice & 9.09 & 324.31 & 13.39 & 0.93 & 1.63 \\
Soybean & 10.97 & 296.17 & 27.38 & 1.21 & 1.48 \\
Maize & 15.55 & 251.14 & 18.42 & 0.80 & 1.94 \\
Sugarcane & 7.64 & 294.33 & 14.15 & 1.54 & 3.21 \\
\hline
\end{tabular}

\section{Conclusions}

ArcSWAT was successfully calibrated and validated for Hamp watershed of upper Mahanadi River basin, with close accuracy and can be successfully utilized to analyse the effect of various management practices on runoff, nutrient loss and sediment yield from the sub-watersheds. The monthly simulation was found to be in close agreement with the observed data sets which was reflected by the high values of statistical indicators. The sediment yield, runoff estimation and nutrient losses matched consistently well with the monthly and seasonal measured values throughout the calibration and validation period. The coefficient of determination $\left(\mathrm{R}^{2}\right)$ of 0.923 and 0.96 for monthly runoff and sediment yield, respectively, indicated very close relationship between measured and predicted sediment yield. The Nash-Sutcliffe efficiency (ENs) was found to be 0.914 and 0.94 for monthly runoff and sediment yield respectively displayed extremely good agreement between the observed and simulated data. The coefficient of determination $\left(R^{2}\right)$ and NashSutcliffe efficiency (ENs) for nutrient losses with values of $\mathrm{NO}_{3}-\mathrm{N}$ (0.746 and 0.736 respectively) and tot-P ( 0.751 and 0.615 , respectively) displayed the capability of the hydrological model for easy and better determination of water and soil quality in the river basin. The critical sub-watersheds were identified on the basis of average sediment yield, runoff and nutrient losses during the period of 2010 to 2013. Out of the 14 sub-watersheds, on the basis of average annual sediment yield, runoff and nutrient loss, sub-watersheds WS4 was considered as most critical watersheds and categorized under high priority for adoption of conservation measures to reduce the soil and runoff loss. HRU 38 with soybean crop over clay loam soil with slope more than $10 \%$ was found to the most critical in respect to sediment yield ( $32.85 \mathrm{t} / \mathrm{ha}$ ) whereas HRU 48 with maize crop over clay loam soil with slope more than $10 \%$ was found to the most critical in respect to nutrient loss $(4.91 \mathrm{~kg} / \mathrm{ha})$. Results showed that rice crop cannot be replaced by other chosen crops (maize, sugarcane and soybean) since these crops resulted in higher sediment yield and nutrient loss as compared to rice. Overall, it can be concluded that any HRU with crop other than rice, over clay loam soil with slope more than $10 \%$ will be yielding more sediment and nutrient and are the most critical HRU for the upper Mahanadi River basin. 


$\begin{array}{ll}\text { Notation } & \\ \text { HRU } & \text { Hydrological Response Unit } \\ \text { SWAT } & \text { Soil and Water Assessment Tool } \\ \text { DEM } & \text { Digital Elevation Model } \\ \text { CWC } & \text { Central Water Commission } \\ \text { MSL } & \text { Mean Sea Level } \\ \text { POWER } & \text { Prediction of Worldwide Energy Resource } \\ \text { SRTM } & \text { Shuttle Radar Topographic Mission } \\ \text { NASA } & \text { National Aeronautics and Space Administration } \\ \text { CGIAR-CSI } & \text { Consultative Group on International Agricultural Re- } \\ & \text { search- Consortium for Spatial Information } \\ \text { UTM } & \text { Universal Transverse Mercator } \\ \text { MLC } & \text { Maximum Likelihood Classifier } \\ \text { GCPs } & \text { Ground Control Points } \\ \text { GPS } & \text { Global Positioning System } \\ \text { NBSS\&LUP } & \text { National Bureau of Soil Survey and Land Use Planning } \\ \text { SCS } & \text { Soil Conservation Service } \\ \text { CN } & \text { Curve Number } \\ \text { SW } & \text { Soil water } \\ \text { R } & \text { Daily Amounts of Precipitation } \\ \text { Q } & \text { Runoff } \\ \text { ET } & \text { Evapotranspiration } \\ \text { P } & \text { Percolation } \\ \text { QR } & \text { Return Flow } \\ \text { MUSLE } & \text { Modified Universal Soil Loss Equation } \\ \text { LH } & \text { Latin Hypercube } \\ \text { OAT } & \text { One-Factor-At-a-Time } \\ \text { R2 } & \text { Coefficient of determination } \\ \text { ENS } & \text { Nash-Sutcliffe efficiency } \\ \text { PBIAS } & \text { Percent bias } \\ & \end{array}$

Patents: Not Applicable.

Author Contributions: Conceptualization, D.K. and M.P.T.; S.P, L.K.; software, M.P.T; validation, S. P., and L.K.; formal analysis, D.K.V.; investigation, D.K.; resources, L.K.; data curation, D.K.; writing-original draft preparation, D.K., M.P.T., A.S., P.S.; writing-review and editing, A.H., N.A.-A. and D.K.V.; visualization, V.K.S.; supervision, M.P.T.; project administration, D.K.; funding acquisition, A.H. and N.A.-A. All authors have read and agreed to the published version of the manuscript.

Funding: This research received no external funding.

Institutional Review Board Statement: Not applicable.

Data Availability Statement: Not applicable.

Acknowledgments: The authors would like to express their gratitude to the Hamp watershed at Andhiyarkhore gauging station of Central Water Commission 112 (CWC), Bhubaneswar, Government of India, and Hydrology Data Center, Department of Water Resources, Government of Chhattisgarh for providing meteorological data for this study. The authors are also thankful to the anonymous reviewers for their valuable comments and suggestions to improve this manuscript further.

Conflicts of Interest: The authors declare no conflict of interest.

\section{Declarations}


Ethical Approval: The paper is submitted only to this Journal for consideration. Consent to Participate: All authors provide consent to Participate in Sustainability. Consent to Publish: All authors provide consent to Publish in Sustainability. Authors Contributions: All authors made great contributions to this study. Funding: Academic Research Work

Competing Interests: The authors declare that they have no known competing financial interests or personal relationships that could have appeared to influence the work reported in this paper.

Availability of data and materials: Available with the authors.

Code availability: Not Applicable.

\section{References}

1. Chaudhary, B.S.; Kumar, S. Soil erosion estimation and prioritization of Koshalya-Jhajhara watershed in North India. Indian J. Soil Conserv. 2018, 46, 305-311.

2. Kumar, S.; Mishra, A. Critical Erosion Area Identification Based on Hydrological Response Unit Level for Effective Sedimentation Control in a River Basin. Water Resour. Manag. 2015, 29, 1749-1765, doi:10.1007/s11269-014-0909-3.

3. Bharti, B. Hydrological Modeling and Evaluation of Best Management Practices in a watershed (Ph.D. thesis), Indian Institute of Technology, Roorkee, 2016.

4. Dickinson, W.T.; Rudra, R.P.; Wall, G.J. Targeting remedial measures to control non- point source pollution. JAWRA J. Am. Water Resour. Assoc. 1990, 26, 499-507, doi:https://doi.org/10.1111/j.1752-1688.1990.tb01388.x.

5. Dillaha, T.A. Role of best management practices in restoring the health of the Chesapeake Bay: 1990-advances in estuarine sciences; 1990;

6. Maas, R.P.; Smolen, M.D.; Dressing, S.A. Selecting critical areas for nonpoint-source pollution control. J. Soil Water Conserv. 1985, 40, 68 LP - 71 .

7. Storm, D.E.; Dillaha III, T.A.; Mostaghimi, S.; Shanholtz, V.O. Modeling phosphorus transport in surface runoff. Trans. ASAE 1988, 31, 117-127, doi:10.13031/2013.30676.

8. Singh, G.; Babu, R.; Narain, P.; Bhushan, L.S.; Abrol, I.P. Soil erosion rates in India. J. Soil Water Conserv. 1992, 47, 97 LP - 99.

9. Ndomba, P.M.; Van Griensven, A. Suitability of SWAT Model for sediment yields modelling in the Eastern Africa, advances in data, methods, models and their applications in geoscience. Tech. Pap. Univ. Dares Salam 2011.

10. Arnold, J.G.; Srinivasan, R.; Muttiah, R.S.; Williams, J.R. Large area hydrologic modeling and assessment part I: model development. JAWRA J. Am. Water Resour. Assoc. 1998, 34, 73-89, doi:https://doi.org/10.1111/j.1752-1688.1998.tb05961.x.

11. Römkens, M.J.M.; Wells, R.R.; Wang, B.; Zheng, F.; Hickey, C.J. Soil Erosion on Upland Areas by Rainfall and Overland Flow BT - Advances in Water Resources Engineering. In; Yang, C.T., Wang, L.K., Eds.; Springer International Publishing: Cham, 2015; pp. 361-405 ISBN 978-3-319-11023-3.

12. Mishra, P.K.; Ramajayam, D.; Sankar, G.R.; Math, S.K.N. Effect of runoff and soil loss on soil hydraulic parameters and forage yield of four grass species under arid vertisols. Indian J. Soil Conserv. 2018, 46, 34-41.

13. Bingner, R.L.; Garbrecht, J.; Arnold, J.G.; Srinivasan, R. Effect of watershed subdivision on simulation runoff and fine sediment yield. Trans. ASAE 1997, 40, 1329-1335, doi:10.13031/2013.21391.

14. Tripathi, M.P.; Panda, R.K.; Raghuwanshi, N.S. Calibration and validation of SWAT model for predicting runoff and sediment yield of a small watershed in India. Int. Agric. Eng. J. 2003, 12, 95-118.

15. Jenson, S.K.; Domingue, J.O. Extracting topographic structure from digital elevation data for geographic information system analysis. Photogramm. Eng. Remote Sensing 1988, 54, 1593-1600.

16. USEPA Quality Criteria for Water; 1976;

17. Willmott, C.J. On the validation of models. Phys. Geogr. 1981, 2, 184-194, doi:https://doi.org/10.1080/02723646.1981.10642213.

18. Vishwakarma, D.K.; Pandey, K.; Kaur, A.; Kushwaha, N.L.; Kumar, R.; Ali, R.; Elbeltagi, A.; Kuriqi, A. Methods to estimate 
evapotranspiration in humid and subtropical climate conditions. Agric. Water Manag. 2022, 261, 107378, doi:https://doi.org/10.1016/j.agwat.2021.107378.

19. Nash, J.E.; Sutcliffe, J. V River flow forecasting through conceptual models part I-A discussion of principles. J. Hydrol. 1970, 10, 282-290, doi:https://doi.org/10.1016/0022-1694(70)90255-6.

20. Shukla, R.; Kumar, P.; Vishwakarma, D.K.; Ali, R.; Kumar, R.; Kuriqi, A. Modeling of stage-discharge using back propagation ANN-, ANFIS-, and WANN-based computing techniques. Theor. Appl. Climatol. 2021, doi:10.1007/s00704-021-03863-y.

21. Gupta, H.V.; Soroosh, S.; Yapo, P.O. Status of Automatic Calibration for Hydrologic Models: Comparison with Multilevel Expert Calibration. J. Hydrol. Eng. 1999, 4, 135-143, doi:10.1061/(ASCE)1084-0699(1999)4:2(135).

22. Moriasi, D.N.; Arnold, J.G.; Van Liew, M.W.; Bingner, R.L.; Harmel, R.D.; Veith, T.L. Model evaluation guidelines for systematic quantification of accuracy in watershed simulations. Trans. ASABE 2007, 50, 885-900, doi:10.13031/2013.23153.

23. Mannering, J. V Use of soil loss tolerances as a strategy for soil conservation. In Proceedings of the Soil conservation problems and prospects:[proceedings of Conservation 80, the International Conference on Soil Conservation, held at the National College of Agricultural Engineering, Silsoe, Beford, UK, 21st-25th July, 1980]/edited by RPC Morgan; Chichester [England], Wiley, c1981., 1981. 